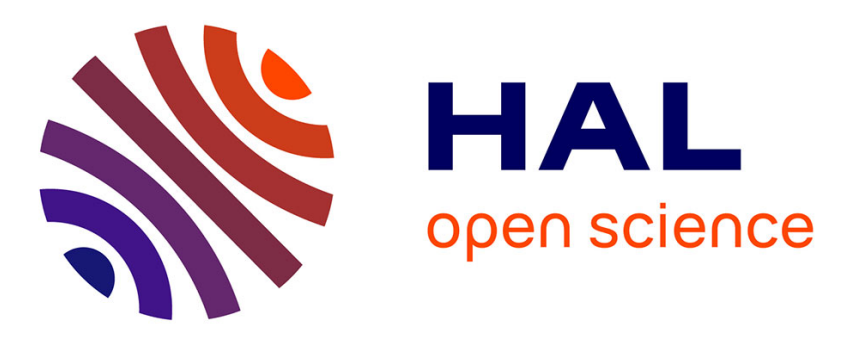

\title{
Metal intracellular partitioning as a detoxification mechanism for mummichogs () living in metal-polluted salt marshes
}

\author{
Daisuke Goto, William G. Wallace
}

\section{- To cite this version:}

Daisuke Goto, William G. Wallace. Metal intracellular partitioning as a detoxification mechanism for mummichogs () living in metal-polluted salt marshes. Marine Environmental Research, 2010, 69 (3), pp.163. 10.1016/j.marenvres.2009.09.008 . hal-00565108

\section{HAL Id: hal-00565108 \\ https://hal.science/hal-00565108}

Submitted on 11 Feb 2011

HAL is a multi-disciplinary open access archive for the deposit and dissemination of scientific research documents, whether they are published or not. The documents may come from teaching and research institutions in France or abroad, or from public or private research centers.
L'archive ouverte pluridisciplinaire HAL, est destinée au dépôt et à la diffusion de documents scientifiques de niveau recherche, publiés ou non, émanant des établissements d'enseignement et de recherche français ou étrangers, des laboratoires publics ou privés. 


\section{Accepted Manuscript}

Metal intracellular partitioning as a detoxification mechanism for mummichogs

(Fundulus heteroclitus) living in metal-polluted salt marshes

Daisuke Goto, William G. Wallace

PII:

S0141-1136(09)00125-1

DOI:

10.1016/j.marenvres.2009.09.008

Reference:

MERE 3374

To appear in:

Marine Environmental Research

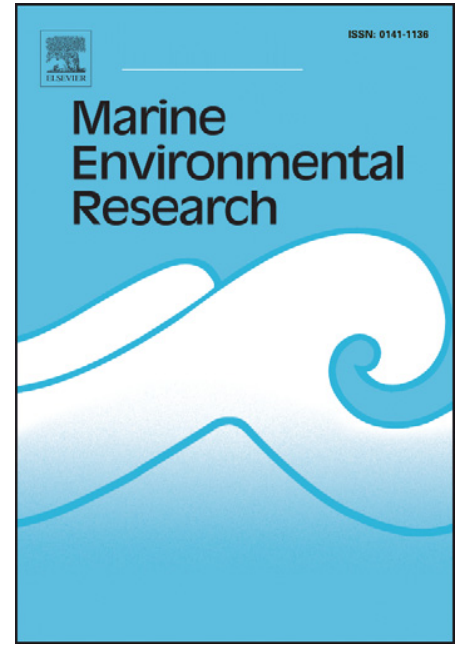

Received Date: $\quad 9$ June 2009

Revised Date: $\quad 6$ August 2009

Accepted Date: $\quad 21$ September 2009

Please cite this article as: Goto, D., Wallace, W.G., Metal intracellular partitioning as a detoxification mechanism for mummichogs (Fundulus heteroclitus) living in metal-polluted salt marshes, Marine Environmental Research (2009), doi: 10.1016/j.marenvres.2009.09.008

This is a PDF file of an unedited manuscript that has been accepted for publication. As a service to our customers we are providing this early version of the manuscript. The manuscript will undergo copyediting, typesetting, and review of the resulting proof before it is published in its final form. Please note that during the production process errors may be discovered which could affect the content, and all legal disclaimers that apply to the journal pertain. 


\section{Metal intracellular partitioning as a detoxification mechanism for mummichogs (Fundulus heteroclitus) living in metal-polluted salt marshes}

Daisuke Goto $^{1, *}$

William G. Wallace ${ }^{1,2}$

${ }^{1}$ Biology Program

Graduate School and University Center

City University of New York

365 Fifth Avenue

New York, New York 10016, USA

${ }^{2}$ Biology Department

College of Staten Island, 6S-310

City University of New York

2800 Victory Boulevard

Staten Island, New York 10314, USA

*Corresponding author

e-mail: daisukegoto@att.net

phone: + 1 (718) 982-3924

fax: + 1 (718) 982-3923 


\begin{abstract}
Intracellular partitioning of trace metals is critical to metal detoxification in aquatic organisms. In the present study, we assessed metal $(\mathrm{Cd}, \mathrm{Cu}, \mathrm{Pb}$, and $\mathrm{Zn})$ handling capacities of mummichogs (Fundulus heteroclitus) in metal-polluted salt marshes in New York, USA by examining metal intracellular partitioning. Despite the lack of differences in the whole body burdens, partitioning patterns of metals in intracellular components (heat-stable proteins, heat-denaturable proteins, organelles, and metal-rich granules) revealed clear differential metal handling capacities among the populations of mummichogs. In general, mummichogs living in metal-polluted sites stored a large amount of metals in detoxifying cellular components, particularly metal-rich granules (MRG). Moreover, only metals associated with MRG were consistently correlated with variations in the whole body burdens. These findings suggest that metal detoxification through intracellular partitioning, particularly the sequestration to MRG, may have important implications for metal tolerance of mummichogs living in chronically metal-polluted habitats.
\end{abstract}

Key words: Metals; forage fish; salt marshes; metal detoxification; metal intracellular partitioning; metal-rich granules; Fundulus heteroclitus; New York, USA 


\section{Introduction}

Trace metal pollution have persistent and cumulative effects that may induce various ecological and physiological effects in marine organisms (Luoma, 1996). In chronically polluted habitats, trace metals can exert selection pressure on the organisms (Klerks and Levinton, 1989; Klerks and Weis, 1987), eliminating local populations of metal-sensitive species and allowing metal-tolerant species to dominate biological communities (Clements, 1997).

Metal tolerance can develop from physiological acclimation as well as genetic adaptation to toxicity of trace metals (Klerks and Levinton, 1989; Klerks and Weis, 1987). Metal-tolerant species generally possess physiological and biochemical mechanisms that allow them to cope with elevated concentrations of bioavailable trace metals in the environment (Mason and Jenkins, 1995; Wang and Rainbow, 2005). Once assimilated, trace metals usually go through a series of metabolic processes in organisms and are subsequently incorporated into various cellular components (Mason and Jenkins, 1995; Wang and Rainbow, 2005). Some metals are sequestered to metal-binding proteins (e.g., metallothioneins) or granular concretions (or metalrich granules) in detoxified forms (Goto and Wallace, 2007; Langston et al., 1998). Metals associated with these detoxifying cellular components, metal-binding proteins and metal-rich granules, can thus be compartmentalized as 'biologically detoxified metals' (BDM), which may indicate species tolerance to metals (Wallace et al., 2003). Metals that are not sequestered into either metal-binding proteins or metal-rich granules may be incorporated into non-detoxifying cellular components (e.g., enzymes and organelles), which could ultimately result in toxicity at various levels of biological organization (Wallace et al., 2003). Metals associated with these nondetoxifying components can thus be compartmentalized as 'metal-sensitive fractions' (MSF), which may indicate species sensitivity to metals (Wallace et al., 2003). 
In the recent years, an increasing number of studies have explored ecological and evolutionary implications for intracellular partitioning of trace metals within marine and freshwater organisms in their natural habitats (Wang and Rainbow, 2006). Some studies have demonstrated that differential tolerance to trace metals among populations or species appears to be related to intracellular metal storage patterns; this relationship may be an important factor in understanding community structure and ecosystem functioning in metal-polluted habitats (e.g., Buchwalter et al., 2007; Cain et al., 2004). Because of its sensitivity to spatial and temporal metal gradients in the environment, intracellular partitioning of trace metals may thus be used to understand metal handling capacities of aquatic organisms chronically exposed to trace metals and to elucidate the mechanisms involved in population- or species-specific tolerance to trace metals.

In the present study, we assessed metal-handling capacities of mummichogs Fundulus heteroclitus (Pisces: Cyprinodontidae) in chronically metal-polluted salt marshes in New York, USA by examining metal intracellular partitioning. Mummichogs are among the most abundant resident forage fishes in tidal creeks and salt marshes in the northwest Atlantic coast (Nixon and Oviatt, 1973; Rountree and Able, 1992). Due to their high tolerance to a variety of anthropogenic stressors, mummichogs can thrive even in severely polluted coastal habitats (Weis, 2002). Like many benthic predators, mummichogs primarily feed on a variety of benthic macroinvertebrates (Kneib et al., 1980), which are in direct contact with sediments (the main source of trace metals in benthic food chains). Furthermore, because of strong site fidelity within salt marshes (Able et al., 2006; McMahon et al., 2005), mummichogs are likely to play an essential role as an intermediate predator (i.e., a conduit of trace metal transfer to top predators) linking sedimentassociated invertebrates to migratory piscivorous fishes and wading birds using salt marshes and 
inland wetlands as feeding grounds (Kneib, 1986). Understanding metal handling capacities of mummichogs would, therefore, provide much needed information on potential ecological impacts of trace metal pollution in urban coastal ecosystems.

\section{Materials and methods}

\subsection{Study area}

This study was conducted in the Arthur Kill-AK (part of the New York/New Jersey-NY/NJ Harbor Estuary Complex), which is a tidal waterway located between northern NJ and Staten Island, NY, connecting Newark Bay and Kill van Kull to the north, and Raritan Bay, NY Harbor, and the Atlantic Ocean to the south (Fig. 1). Due to chronic pollution (e.g., chemical discharges from industrial facilities and sewage treatment plants), the water quality of the NY/NJ Harbor Estuary has been severely degraded for more than a century (Crawford et al., 1994). The highest concentrations of some chemical pollutants occur in tributaries of AK (Weis et al., 2001). Since tides enter from both ends of $\mathrm{AK}$, this region is poorly flushed, resulting in enhanced entrapment and accumulation of pollutants in sediments (Adams and Benyi, 2003).

Specific sampling sites were four tributaries of AK; Richmond Creek, Main Creek, Neck Creek, and Mill Creek and two regional reference sites external to AK; Lemon Creek and Great Kills Harbor (Fig. 1; Table 1: trace metal data from Goto and Wallace, In press). Neck Creek is polluted with various chemicals due to its proximity to many oil refineries as well as abandoned industrial facilities. Richmond Creek and Main Creek are tributaries of Fresh Kills Complex, which is surrounded by the Fresh Kills landfill. Mill Creek is located near the confluence of AK and Raritan Bay and has been polluted from historic smelting activities in the area. Lemon Creek is one of a few relatively undisturbed tidal salt marshes in the region. Despite its proximity to 
sewage treatment plants, Great Kills Harbor, which is located on the eastern shore of Staten Island, has relatively low concentrations of chemical pollutants.

\subsection{Sampling and laboratory processing of mummichogs}

Sampling of mummichogs was conducted during the summer (June to August) of 2004 (two to three times per month). Large adult mummichogs (70-90 mm TL, $n=\sim 100$ per site) were collected using a $3.05 \times 1.22 \mathrm{~m}$-seine net or cylindrical minnow trap. In the laboratory, to minimize measurement errors associated with unassimilated metals in the gut contents, randomly chosen samples of mummichogs ( $n=\sim 20$ per site) were allowed to depurate gut contents for at least 24 hours in filtered $15 \%$ seawater. Mummichogs were then immediately euthanized by an overdose of MS222, and the whole body was stored in a freezer $\left(-80^{\circ} \mathrm{C}\right)$ for subsequent fractionation and metal analyses (Sections 2.3 and 2.4).

\subsection{Intracellular partitioning of metals in mummichogs}

Intracellular partitioning of trace metals within mummichogs was examined using the established method by Wallace et al. (2003) with minor modifications. This method produces four major operationally defined fractions, i.e., organelles (ORG), heat-denatured proteins (HDP), heat-stable proteins (HSP), and metal-rich granules (MRG), which are compartmentalized as either metal-sensitive fraction $(\mathrm{MSF}=\mathrm{ORG}+\mathrm{HDP})$ or biologicallydetoxified metal (BDM = HSP + MRG); and "cellular debris" (CD), whose functions are not well defined (Wallace et al., 2003). Previously depurated and frozen mummichogs $(n=10$ per site) (Section 2.2) were thawed on ice and homogenized in cold TRIS buffer ( $\mathrm{pH}=7.6)$ with a Polytron tissue homogenizer under a nitrogen atmosphere. Then, subsamples $(n=10$; each 
sample $=\sim 5-8 \mathrm{~g}$ wet tissues) of homogenates were fractionated using differential centrifugation (Wallace et al., 2003) under a nitrogen atmosphere. Briefly, homogenized fish tissues were centrifuged at $1,450 \times \mathrm{g}$ for 15 minutes, which produced a supernate (S1) and a pellet (P1). S1 was further centrifuged at $100,000 \times \mathrm{g}$ for 60 minutes, which resulted in a supernate (S2) containing cytosol and a pellet $(\mathrm{P} 2)$ containing $\mathrm{ORG}$. After heat treatment $\left(80^{\circ} \mathrm{C}\right)$ for one hour, S2 was fractionated by ten-minute $30,000 \times \mathrm{g}$ centrifugation into a supernate (S3) containing HSP and a pellet (P3) (= HDP). P2 was vortexed with sodium hydroxide (1 M) and centrifuged further at 5,000 $\mathrm{x} g$ for ten minutes to isolate MRG (P4) from other cellular fragments (CD) (S4). All fractions were processed for metal analyses as described below (Section 2.4). As a quality control, the sum of concentrations for each metal [cadmium $(\mathrm{Cd})$, copper $(\mathrm{Cu})$, lead $(\mathrm{Pb})$, or zinc $(\mathrm{Zn})]$ in the five fractions $(=\mathrm{ORG}+\mathrm{HSP}+\mathrm{HDP}+\mathrm{MRG}+\mathrm{CD})$ was compared with the concentrations in subsamples taken from the initial total homogenates. Recovery rates of the homogenates subsequent to fractionation were consistently high $(\mathrm{Cd}: 92-110 \%$; $\mathrm{Pb}$ : 94-105\%; $89-110 \% ; 90-110 \%)$.

\subsection{Analyses of metals in mummichogs}

Resultant supernates and pellets from fractionations as well as homogenized whole body of mummichogs were oven-dried $\left(\sim 70^{\circ} \mathrm{C}\right)$ for 24 to 48 hours and weighed (dry weight). Samples were then digested under reflux with concentrated Trace Metal Grade nitric acid (5 ml) overnight at room temperature $\left(\sim 20^{\circ} \mathrm{C}\right)$ and subsequently on a hotplate $\left(\sim 80^{\circ} \mathrm{C}\right)$ for $\sim 48$ to 72 hours (Csuros and Csuros, 2002). Once digested, samples were evaporated to dryness, re-suspended in $2 \%$ nitric acid $(8 \mathrm{ml})$, and filtered $(0.45 \mu \mathrm{m})$. Metal concentrations in samples were analyzed 
with graphite furnace atomic absorption spectrometer for $\mathrm{Cd}, \mathrm{Cu}$, and $\mathrm{Pb}$, or flame atomic absorption spectrophotometer for Zn (Perkin Elmer 3100AAS with AS-60).

As quality assurance, Standard Reference Material ${ }^{\circledR}$ (mussel tissue, SRM 2976, National Institute of Standards and Technology, USA) was processed and analyzed for $\mathrm{Cd}, \mathrm{Cu}, \mathrm{Pb}$, and $\mathrm{Zn}$, as described above. The average recovery rates of $\mathrm{Cd}, \mathrm{Cu}, \mathrm{Pb}$, and $\mathrm{Zn}$ were 95.3, 100.3, 63.5 (note that due to its low recovery rate, the concentration results for $\mathrm{Pb}$ need to be carefully considered), and 96.3\%, respectively. Procedural and reagent blanks were also analyzed for potential secondary metal contamination. Select calibration standard solutions of each metal were analyzed every 10 samples. When the deviation from the initial values was more than $\pm 10 \%$, the instrument was recalibrated. The correlation coefficients of calibration curves were maintained $>$ 0.999 for the analysis. All standard solutions and samples were prepared with NANOpure ${ }^{\circledR}$ (reagent-grade) water. All glassware was soaked in 10\% hydrochloric acid overnight, rinsed once with deionized water, and rinsed twice with NANOpure ${ }^{\circledR}$ water.

\subsection{Statistical analyses}

The normality of data was tested using Shapiro-Wilk's $W$ test. The homogeneity of variance was tested using Levene's test. Proportional data were arcsine-transformed, and concentration data were $\log _{10}$-transformed before analyses, when necessary. The statistical significance of differences in whole body burdens of mummichogs among study sites was tested using one-way analysis of variance (ANOVA), which, if significant, was followed by Tukey's honestly significant difference (HSD) test. Relationships between concentration of metals associated with each intracellular fraction and whole body burden were tested using least squares regression, 
which was fitted by the Levenberg-Marquardt algorithm. All univariate statistical analyses were performed using Statistica 7.1 (Statsoft, Inc ${ }^{\circledR}$, USA).

The statistical significance of differences in metal intracellular partitioning patterns (in concentration, $\mu \mathrm{g} \cdot \mathrm{g}^{-1}$, dry weight) among populations was tested using one-way analysis of similarity (ANOSIM) (Clarke and Gorley, 2006). ANOSIM was performed on square roottransformed data with randomization permutation $(n=9999)$ of Bray-Curtis similarity index at the significance level of 5\%, which, if significant, was followed by pairwise comparisons (Clarke and Gorley, 2006). ANOSIM was performed using PRIMER v6.1.9 (PRIMER-E Ltd, Plymouth, UK).

\section{Results}

\subsection{Metal bioaccumulation in mummichogs}

With the exception of $\mathrm{Pb}$, there was no significant difference in whole body burdens of metals in mummichogs among the populations $\left(\mathrm{Cd}: \sim 0.036 \mu \mathrm{g} \cdot \mathrm{g}^{-1}\right.$ dry weight; $\mathrm{Cu}: \sim 11 \mu \mathrm{g} \cdot \mathrm{g}^{-1} \mathrm{dry}$ weight; $\mathrm{Zn}: \sim 160 \mu \mathrm{g} \cdot \mathrm{g}^{-1}$ dry weight, Table 2 ). The $\mathrm{Pb}$ whole body burden in mummichogs from Mill Creek was significantly $(\sim 2$-fold $)$ higher $\left(1.3 \mu \mathrm{g} \cdot \mathrm{g}^{-1}\right.$ dry weight $)$ than those from the other sites $\left(\sim 0.72 \mu \mathrm{g} \cdot \mathrm{g}^{-1}\right.$ dry weight) (Tukey’s HSD test, $\left.p<0.05\right)$ (Table 2$)$.

\subsection{Intracellular partitioning of metals in mummichogs}

Despite the lack of significant differences in metal bioaccumulation (except for $\mathrm{Pb}$ ), there were significant differences in intracellular partitioning [heat-stable proteins (HSP), heatdenaturable proteins (HDP), organelles (ORG), and metal-rich granules (MRG)] of metals within mummichogs among the populations. The results of one-way ANOSIM also showed that 
although the intracellular partitioning of $\mathrm{Cd}$ and $\mathrm{Zn}$ were significantly different among the populations (Cd: $p=1.9 \%, \mathrm{Zn}: p=0.05 \%)$, the global $R$ values for the among-population comparisons $(\mathrm{Cd}: R=0.116, \mathrm{Zn}: R=0.207)$ were much lower than that for $\mathrm{Pb}(R=0.671, p=$ $0.05 \%)$. There was no significant difference in $\mathrm{Cu}$ partitioning among the populations $(R=$ $0.059, p=11 \%$ ). The post-hoc pairwise comparisons indicated that a significant difference in Cd partitioning was observed only between Great Kills Harbor and Main Creek $(R=0.246, p=$ $1.5 \%)$, Lemon Creek and Neck Creek $(R=0.263, p=1.4 \%)$, and Neck Creek and Mill Creek $(R$ $=0.241, p=4.7 \%$ ) (Fig. 2a). For Pb, with an exception of a comparison between Neck Creek and Richmond Creek $(R=0.121, p=11.1 \%)$, all pairwise comparisons were significant $(R=$ 0.252 to $1.000, p=0.02$ to $3.2 \%$ ) (Fig. 2 b). The $\mathrm{Zn}$ partitioning in the Lemon Creek population was significantly different from that in fish from Neck Creek $(R=0.498, p=0.2 \%)$, Richmond Creek $(R=0.508, p=0.4 \%)$, and Main Creek $(R=0.422, p=0.4 \%)$, while the Zn partitioning in the Great Kills Harbor population was significantly different only from that in fish from Neck Creek $(R=0.354, p=0.3 \%)($ Fig. $2 \mathrm{~d})$.

Proportions of $\mathrm{Cd}$ partitioned as biologically-detoxified metals $(\mathrm{BDM}=\mathrm{HSP}+\mathrm{MRG})$ varied considerably among the populations (26\% at Neck Creek to $40.8 \%$ at Mill Creek) (Fig. 2a). In contrast, the proportions of $\mathrm{Cd}$ partitioned to metal-sensitive fractions (MSF $=\mathrm{ORG}+\mathrm{HDP}$ ) were fairly similar among the populations $(\sim 21 \%)$, except for the Lemon Creek population $(30.5 \%)$ (Fig. 2a). With the exception of mummichogs from Lemon Creek and Great Kills Harbor, a considerable proportion of $\mathrm{Pb}(46.2 \%$ to $63.1 \%)$ was stored in BDM (more than $50 \%$ of $\mathrm{Pb}$ in the Mill Creek population was partitioned to $\mathrm{MRG}$ ), whereas only $\sim 8 \%$ was stored in MSF (Fig. 2b). A relatively higher proportion of $\mathrm{Pb}$ in mummichogs from Lemon Creek and Great Kills Harbor $(\sim 19 \%)$ was stored in HSP than fish from the other populations $(5.1 \%$ to 
$15.5 \%$ ) (Fig. 2 b). In general, $\sim 23 \%$ of $\mathrm{Cu}$ in mummichogs was partitioned to MSF, while $\sim 30 \%$ of $\mathrm{Cu}$ was partitioned to BDM (Fig. 2c). Mummichogs stored a large proportion of $\mathrm{Zn}(37.4 \%$ to $45.9 \%)$ as BDM, particularly MRG (35.0\% to $43.1 \%)$, but only $\sim 2.5 \%$ of $\mathrm{Zn}$ was partitioned to HSP (Fig. 2d).

Concentrations of $\mathrm{Cd}$ partitioned to $\mathrm{HSP}, \mathrm{HDP}, \mathrm{ORG}$, and MRG were all significantly correlated with the whole body burdens (Fig. 3a). Although concentrations of $\mathrm{Pb}$ partitioned to all intracellular fractions were significantly correlated with the whole body burdens, they reached an asymptote at whole body burdens of $\sim 1 \mu \mathrm{g} \cdot \mathrm{g}^{-1}$ dry weight, except for that partitioned to MRG, which had a linear relation with the whole body burdens (Fig. 3b). Similarly, Cu partitioned to HSP, HDP, and ORG all reached an asymptote at the whole body burdens $=\sim 15 \mu \mathrm{g}^{-\mathrm{g}^{-1}} \mathrm{dry}$ weight, while $\mathrm{Cu}$ partitioned to MRG continued to increase with the whole body burdens (Fig. 3c). Unlike $\mathrm{Cd}, \mathrm{Pb}$, and $\mathrm{Cu}$, only concentrations of $\mathrm{Zn}$ partitioned to $\mathrm{MRG}$ were significantly correlated with the whole body burdens (Fig. 3d).

\section{Discussion}

The importance of intracellular partitioning of trace metals for metal tolerance has been increasingly recognized for various marine and freshwater organisms in metal-polluted habitats (Wang and Rainbow, 2006). Although there have been many field studies on metal pollution impacts on fish (e.g., metal bioaccumulation and toxicity) in marine and freshwater ecosystems, these studies often focus on whole body burdens (e.g., Clements and Rees, 1997). Whole body burdens are, however, often not conclusive in understanding metal pollution impacts on fishes and shellfishes (Clements and Rees, 1997; Farag et al., 1999). Mummichogs examined in the present study are well known for their high tolerance to elevated concentrations of chemical 
pollutants (Weis, 2002), thriving even in severely polluted coastal environments (Able et al., 1998). Moreover, there is evidence that mummichogs do not accumulate some metals even in highly metal-polluted habitats (e.g., Khan and Weis, 1993). For example, a population of mummichogs from a metal-polluted site in the Arthur Kill $(\mathrm{AK})\left(\mathrm{Cd}\right.$ in sediments $=5.8 \mu \mathrm{g} \cdot \mathrm{g}^{-1}$ wet weight $)$ accumulated about the same amount of $\mathrm{Cd}\left(0.38 \mu \mathrm{g} \cdot \mathrm{g}^{-1}\right.$ wet weight $)$ as a population of mummichogs from a pristine site in New York $\left(\mathrm{Cd}\right.$ in sediments $=0.46 \mu \mathrm{g} \cdot \mathrm{g}^{-1}$; $\mathrm{Cd}$ in fish $=$ $0.39 \mu \mathrm{g} \cdot \mathrm{g}^{-1}$ wet weight) (Khan and Weis, 1993). Metal intracellular partitioning within mummichogs in the present study may provide an insight into physiological and biochemical mechanisms for metal bioaccumulation and high tolerance to metals in the environment.

\subsection{Intracellular partitioning of cadmium (Cd)}

The results from the current study showed that consistently higher proportions of $\mathrm{Cd}(26 \%$ to $41 \%$ ) in mummichogs were partitioned as biologically-detoxified metals (BDM) than metalsensitive fractions (MSF), which varied relatively little among the populations $(\sim 22 \%$, except for the Great Kills population=31\%). A similar pattern was also observed in yellow perch Perca flavescens; in the liver of yellow perch collected from metal-polluted lakes in Canada, for example, proportions of $\mathrm{Cd}$ associated with intracellular fractions were generally constant, except for that associated with metal-binding proteins (Giguere et al., 2006), suggesting that Cd in these fish was likely to be regulated (Giguere et al., 2006; Kraemer et al., 2006). Moreover, Cd concentrations in all intracellular fractions (including metal-binding proteins) in mummichogs in the present study continued to increase with the whole body burdens without showing any threshold. Mummichogs may have exhibited these intracellular partitioning patterns due to low Cd available in the environment (both sediments and food). However, a similar 
partitioning pattern was also found in other fish (e.g., yellow perch, Campbell et al., 2008;

Giguere et al., 2006) and invertebrate (e.g., zebra mussels, Voets et al., 2009) species from highly Cd-polluted habitats, suggesting that a toxicity threshold concept may not be applicable in field chronic Cd-exposures.

Although concentrations in the sources of Cd exposure (sediments and grass shrimp) were generally low and varied little among sites, and no significant difference was observed in $\mathrm{Cd}$ bioaccumulation in mummichogs, $\mathrm{Cd}$ intracellular partitioning revealed different $\mathrm{Cd}$ handling patterns among the populations. In general, proportions of $\mathrm{Cd}$ partitioned to both heat-stable proteins (HSP) and metal-rich granules (MRG) was equal ( $16 \%)$ within BDM of all populations, except for the Neck Creek and Mill Creek populations. Interestingly, the Neck Creek population partitioned four times more Cd to HSP than MRG, while the Mill Creek population partitioned two times more Cd to MRG than HSP. In general, studies on Cd intracellular partitioning have generally shown that chronically Cd-exposed marine and freshwater organisms tend to store increasingly more Cd to insoluble fractions (e.g., MRG), as the organisms accumulate more Cd in their body (e.g., Bonneris et al., 2005a; Bustamante et al., 2002; Ng and Wang, 2005). The population-specific Cd partitioning may thus imply that the sequestration into insoluble granules is more efficient in detoxifying $\mathrm{Cd}$ than metal-binding proteins, allowing aquatic organisms living in metal-polluted habitats to tolerate an elevated concentration of $\mathrm{Cd}$ in the environment. Wallace et al. (1998) have, for instance, demonstrated that a population of a deposit-feeding oligochaete Limnodrilus hoffmeisteiri living in metalpolluted habitats preferentially sequestered cadmium $(\mathrm{Cd})$ to $M R G$, whereas a population of $L$. hoffmeisteiri from non-polluted habitats sequestered the majority of Cd into HSP. 
Intracellular partitioning of metals may also reflect some different metal handling capacities among populations in response to metal exposure history (Wang and Rainbow, 2005). In general, there are considerable differences in metal handling by aquatic organisms between acute and chronic (or lab- and field- based) exposures (Campbell et al., 2005). Although Cd concentrations in AK have been declining over time, AK has a long history of metal pollution (Crawford et al., 1994). It is thus possible that some AK populations of mummichogs may have been able to retain their metal handling capacities, resulting differential $\mathrm{Cd}$ intracellular partitioning among the populations. Since Cd intracellular partitioning can be influenced not only by bioavailable $\mathrm{Cd}$ concentrations in the environment (sediments or food), but also biological and physicochemical factors, including organisms' exposure history to other metals (Morgan et al., 2007; Wang and Rainbow, 2005), differential Cd handling among the populations observed in the present study may also indicate their potential overall metal tolerance.

\subsection{Intracellular partitioning of lead $(\mathrm{Pb})$}

Unlike $\mathrm{Cd}, \mathrm{Pb}$ intracellular partitioning has been investigated in only a few marine and freshwater species (e.g., Bustamante et al., 2006; Raimundo et al., 2008); its detoxification mechanisms are thus poorly understood. In the current study, the lack of difference in $\mathrm{Pb}$ whole body burden $\left(\sim 0.72 \mu \mathrm{g} \cdot \mathrm{g}^{-1}\right.$ dry weight) in mummichogs among populations (except for the Mill Creek population, $1.3 \mu \mathrm{g} \cdot \mathrm{g}^{-1}$ dry weight $)$ appeared to reflect $\mathrm{Pb}$ whole body burdens $\left(\sim 0.71 \mu \mathrm{g} \cdot \mathrm{g}^{-}\right.$ 1 dry weight) in prey (grass shrimp), rather than sediment-associated $\mathrm{Pb}$ concentrations (84-660 $\mu \mathrm{g} \cdot \mathrm{g}^{-1}$ dry weight). However, there were substantial differences in $\mathrm{Pb}$ intracellular partitioning among the populations. In general, a large proportion (46-63\%) of $\mathrm{Pb}$ in the $\mathrm{AK}$ populations of mummichogs was stored as BDM, mostly associated with MRG (33-58\%), while the Lemon 
Creek and Great Kills Harbor (reference) populations stored only $\sim 27 \%$ of $\mathrm{Pb}$ as BDM and sequestered equal proportions ( $14 \%)$ of $\mathrm{Pb}$ into HSP and MRG. Among the AK populations, the Mill Creek population, which accumulated more than twice as much $\mathrm{Pb}$ as the other populations [reflecting elevated concentrations in both sediments $\left(660 \mu \mathrm{g} \cdot \mathrm{g}^{-1} \mathrm{dry}\right.$ weight $)$ and grass shrimp $\left(1.2 \mu \mathrm{g} \cdot \mathrm{g}^{-1}\right.$ dry weight)], partitioned more than half $(58 \%)$ of $\mathrm{Pb}$ in their body to MRG. In fact, only concentrations of $\mathrm{Pb}$ associated with MRG consistently increased with the whole body burdens, suggesting a potential indicator for physiological responses to $\mathrm{Pb}$ by mummichogs. Studies on aquatic invertebrates living in metal-polluted environments have reported that $\mathrm{Pb}$ is often preferentially $(\geq 60 \%)$ partitioned to insoluble fractions (e.g., Cain et al., 2000; Goto and Wallace, In press). Metal-tolerant aquatic insects living in highly metal-polluted streams, for instance, sequester a substantial amount of $\mathrm{Pb}$ (more than $95 \%$ of the whole body burdens) into an insoluble cellular component (Cain et al., 2000). These partitioning patterns further emphasize the importance of insoluble granules as a detoxification mechanism, allowing aquatic organisms living in metal-polluted habitats to tolerate an elevated concentration of nonessential metals.

\subsection{Intracellular partitioning of copper $(\mathrm{Cu})$}

In spite of highly elevated concentrations of sediment-associated $\mathrm{Cu}$ (up to $1400 \mu \mathrm{g} \cdot \mathrm{g}^{-1} \mathrm{dry}$ weight) as well as their potential dietary sources of $\mathrm{Cu}$ (up to $200 \mu \mathrm{g} \cdot \mathrm{g}^{-1}$ dry weight in Palaemonetes pugio), mummichogs accumulated a relatively low amount of $\mathrm{Cu}\left(\sim 10 \mu \mathrm{g} \cdot \mathrm{g}^{-1} \mathrm{dry}\right.$ weight). Weis and Weis (1999) have also demonstrated in a three-month field transplant experiment that mummichogs accumulated much less $\mathrm{Cu}$ than crustaceans such as $P$. pugio. Furthermore, there was no difference in $\mathrm{Cu}$ intracellular partitioning among the populations in 
the current study; mummichogs generally partitioned more $\mathrm{Cu}$ as BDM (24\% to $34 \%$ ) than MSF (19\% to $27 \%$ ). Unlike $\mathrm{Cd}$ and $\mathrm{Pb}$, however, as $\mathrm{Cu}$ is an essential metal, the intracellular partitioning of $\mathrm{Cu}$ should be interpreted differently; the partitioning to MSF does not necessarily reflect its potential toxicity (Hamza-Chaffai et al., 1995), especially at the low concentrations $\left(\sim 2.4 \mu \mathrm{g} \mathrm{Cu} \cdot \mathrm{g}^{-1}\right.$ dry weight) observed in the current study. Furthermore, among the intracellular fractions, only the concentrations of $\mathrm{Cu}$ associated with $\mathrm{MRG}$ were consistently responsive to the whole body burdens, while those associated with the other fractions quickly reached an asymptote at $\sim 15 \mu \mathrm{g} \cdot \mathrm{g}^{-1}$ dry weight. It is thus possible that mummichogs may have been able to efficiently eliminate unnecessary $\mathrm{Cu}$ after storing it in insoluble cellular components as a detoxified form. This was contrary to the findings in previous studies, in which tissue (e.g., liver)-specific $\mathrm{Cu}$ is often increasingly associated with HSP (particularly metallothioneins) in fish, as total $\mathrm{Cu}$ burdens increase (Giguere et al., 2006; Kraemer et al., 2006). Since the present study was based on the whole body of fish, tissue-specific intracellular partitioning dynamics may not have been reflected at the whole body level.

\subsection{Intracellular partitioning of zinc $(\mathrm{Zn})$}

Zinc bioaccumulation in mummichogs was also fairly similar among the populations $(\sim 150$ $\mu \mathrm{g} \mathrm{Zn} \cdot \mathrm{g}^{-1}$ dry weight). Unlike $\mathrm{Cu}$, however, both the $\mathrm{AK}$ and reference populations of mummichogs accumulated a substantial amount of $\mathrm{Zn}$ in their body, which was much higher than $\mathrm{Zn}$ whole body burdens in prey, $P$. pugio $\left(\leq 100 \mu \mathrm{g} \cdot \mathrm{g}^{-1}\right.$ dry weight $)$. Furthermore, a large proportion $(\sim 37 \%$ to $\sim 46 \%)$ of $\mathrm{Zn}$ accumulated in all populations of mummichogs was stored as BDM, particularly MRG ( $35 \%$ to $\sim 45 \%)$, which was also the only fraction that had a significant relationship with the whole body burdens. Only $\sim 2.5 \%$ of $\mathrm{Zn}$ accumulated in mummichogs, 
which was even lower than Zn associated with HDP ( 7.9\%), was partitioned to HSP. These partitioning patterns are more similar to those in aquatic invertebrates (e.g., bivalves, Bonneris et al. 2005a) than those in other fish (e.g., yellow perch, Giguere et al., 2006). The importance of MRG as a detoxification mechanism for $\mathrm{Zn}$ has not been extensively investigated for fish. Studies on aquatic invertebrates have shown, however, that $\mathrm{Zn}$ is one of the major components of phosphate-based MRG (Brown, 1982; Masala et al., 2004; Mason and Nott, 1981). Moreover, Sauer and Watabe (1984) have demonstrated that a considerable amount (up to $\sim 19 \%$ of the whole body burdens) of $\mathrm{Zn}$ in mummichogs is deposited (replacing calcium) in scales, and some $\mathrm{Zn}$ is ultimately eliminated, suggesting that the temporary deposition of excess $\mathrm{Zn}$ in calcified structures may also be a Zn detoxification strategy for fish (Sauer and Watabe, 1989). Since the results from the present study were based on the whole body of fish, it is difficult to assess the relative importance of MRG and scale deposition. Based on the findings from the present as well as previous studies, however, both $\mathrm{Zn}$ sequestration to MRG and deposition to calcified structures are likely to be part of important detoxification or regulatory mechanisms that allow mummichogs to accumulate a considerable amount of $\mathrm{Zn}$ in their body.

\section{Conclusions}

Since benthic organisms living in metal-polluted habitats are constantly exposed to trace metals via sediments and food, benthic forage fish such as mummichogs are likely to develop detoxification strategies to tolerate elevated concentrations of metals over time. The results of the present study suggest that metal whole body burdens in mummichogs generally reflect those in prey, rather than sediment-associated metal concentrations, indicating the importance of food as metal exposure pathways in the field. Furthermore, metal intracellular partitioning within 
mummichogs revealed some subtle differences in metal handling capacities among the populations, which may be associated with potential mechanisms to tolerate elevated concentrations of trace metals available in the environment. In general, metals appeared to be equally partitioned as the metal-sensitive fraction (MSF) and biologically detoxified metal (BDM) at low exposure levels (in this study, at the reference sites as well as some of the AK sites). However, when mummichogs were chronically exposed to elevated concentrations of metals, metals were preferentially partitioned as BDM, particularly insoluble metal-rich granules (MRG). This differential intracellular partitioning was not always reflected in the whole body burdens.

This study was based on the whole body of mummichogs, rather than specific tissues such as liver or kidney used in other studies (e.g., Giguere et al., 2006). Some differential tissue-specific accumulation and intracellular partitioning patterns are, however, known to exist within aquatic organisms (e.g., Bonneris et al., 2005b; Hamza-Chaffai et al., 1995). Further studies incorporating biological (e.g., tissue-specific distributions) as well as ecological (e.g., seasons, sex, and age) factors thus still need to be conducted to understand the importance of detoxification processes, particularly the sequestration to $\mathrm{MRG}$, in assessing secondary implications of intracellular partitioning of trace metals (e.g., metal transfer in food webs, Seebaugh et al., 2005).

\section{Acknowledgement}

This project was supported in part by PSC-CUNY Research Award (\# 66247-00 35) and the Graduate Center, the City University of New York under the Doctoral Student Research Grant Program. Additional funding was also provided by New York Sea Grant (project number, 
R/CTP-39) funded under award \# NA16RG1645 from the National Sea Grant College Program of the U.S. Department of Commerce's National Oceanic and Atmospheric Administration, to the Research Foundation of State University of New York on behalf of New York Sea Grant. The statements, findings, conclusions, views, and recommendations are those of the author(s) and do not necessarily reflect the views of any of those organizations. We greatly appreciate field and laboratory assistance provided by D. Seebaugh, M. Perez, J. Khoury, A. Bernick, A. Estephan, M. Murphy, A. Ferretti, and the Interstate Environmental Commission laboratory, as well as useful comments provided by R.R. Veit, J.W. Rachlin, J.R. Waldman, P. Weis, and four anonymous reviewers.

\section{References}

Able, K.W., Hagan, S.M., Brown, S.A., 2006. Habitat use, movement, and growth of young-ofthe-year Fundulus spp. in southern New Jersey salt marshes: comparisons based on tag/recapture. J. Exp. Mar. Biol. Ecol. 335, 177-187.

Able, K.W., Manderson, J.P., Studholme, A.L., 1998. The distribution of shallow water juvenile fishes in an urban estuary: the effects of manmade structures in the lower Hudson River. Estuaries 21, 731-744.

Adams, D.A., Benyi, S., 2003. Sediment quality of the NY/NJ Harbor System: a 5-year revisit. An investigation under the Regional Environmental Monitoring and Assessment Program (REMAP). U.S. Environmental Protection Agency - Region 2, Edison, NJ.

Bonneris, E., Giguere, A., Perceval, O., Buronfosse, T., Masson, S., Hare, L., Campbell, P.G.C., 2005a. Sub-cellular partitioning of metals $(\mathrm{Cd}, \mathrm{Cu}, \mathrm{Zn})$ in the gills of a freshwater bivalve, 
Pyganodon grandis: role of calcium concretions in metal sequestration. Aquat. Toxicol. 71, 319334.

Bonneris, E., Perceval, O., Massona, S., Hare, L., Campbell, P.G.C., 2005b. Sub-cellular partitioning of $\mathrm{Cd}, \mathrm{Cu}$ and $\mathrm{Zn}$ in tissues of indigenous unionid bivalves living along a metal exposure gradient and links to metal-induced effects. Environ. Pollut. 135, 195-208.

Brown, B.E., 1982. The form and function of metal containing 'granules' in invertebrate tissues. Biol. Rev. Camb Phil. Soc. 57, 621-667.

Buchwalter, D.B., Cain, D.J., Clements, W.H., Luoma, S.N., 2007. Using biodynamic models to reconcile differences between laboratory toxicity tests and field biomonitoring with aquatic insects. Environ. Sci. Technol. 41, 4821-4828.

Bustamante, P., Bertrand, M., Boucaud-Camou, E., Miramand, P., 2006. Subcellular distribution of $\mathrm{Ag}, \mathrm{Cd}, \mathrm{Co}, \mathrm{Cu}, \mathrm{Fe}, \mathrm{Mn}, \mathrm{Pb}$, and $\mathrm{Zn}$ in the digestive gland of the common cuttlefish Sepia officinalis. J. Shell. Res. 25, 987-993.

Bustamante, P., Cosson, R.P., Gallien, I., Caurant, F., Miramand, P., 2002. Cadmium detoxification processes in the digestive gland of cephalopods in relation to accumulated cadmium concentrations. Mar. Environ. Res. 53, 227-241.

Cain, D.J., Carter, J.L., Fend, S.V., Luoma, S.N., Alpers, C.N., Taylor, H.E., 2000. Metal exposure in a benthic macroinvertebrate, Hydropsyche californica, related to mine drainage in the Sacramento River. Can. J. Fish. Aquat. Sci. 57, 380-390. 
Cain, D.J., Luoma, S.N., Wallace, W.G., 2004. Linking metal bioaccumulation of aquatic insects to their distribution patterns in a mining-impacted river. Environ. Toxicol. Chem. 23, 14631473.

Campbell, P.G.C., Giguere, A., Bonneris, E., Hare, L., 2005. Cadmium-handling strategies in two chronically exposed indigenous freshwater organisms--the yellow perch (Perca flavescens) and the floater mollusc (Pyganodon grandis). Aquat. Toxicol. 72, 83-97.

Campbell, P.G.C., Kraemer, L.D., Giguère, A., Hare, L., Hontela, A., 2008. Subcellular distribution of cadmium and nickel in chronically exposed wild fish: inferences regarding metal detoxification strategies and implications for setting water quality guidelines for dissolved metals. Hum. Ecol. Risk Assess. 14, 290-316.

Clarke, K.R., Gorley, R.N., 2006. PRIMER v6: User manual/tutorial. PRIMER-E Ltd, Plymouth. Clements, W.H., 1997. Effects of contaminants at higher levels of biological organization in aquatic ecosystems. Rev. Toxicol. 1, 107-146.

Clements, W.H., Rees, D.E., 1997. Effects of heavy metals on prey abundance, feeding habits, and metal uptake of brown trout (Salmo trutta) in the Arkansas River, Colorado. Trans. Am. Fish. Soc. 126, 774-785.

Crawford, D.W., Bonnevie, N.L., Gillis, C.A., Wenning, R.J., 1994. Historical changes in the ecological health of the Newark Bay Estuary, New Jersey. Ecotoxicol. Environ. Safety 29, 276303. 
Csuros, M., Csuros, C., 2002. Environmental sampling and analysis of metals. Lewis Publishers, Boca Raton, Florida.

Farag, A.M., Woodward, D.F., Goldstein, J.N., E., M., Hogstrand, C., T., B.F., 1999. Dietary effects of metals-contaminated invertebrates from the Coer d'Alene River, Idaho, on cutthroat trout. Trans. Am. Fish. Soc. 128, 578-592.

Giguere, A., Campbell, P.G.C., Hare, L., Couture, P., 2006. Sub-cellular partitioning of cadmium, copper, nickel and zinc in indigenous yellow perch (Perca flavescens) sampled along a polymetallic gradient. Aquat. Toxicol. 77, 178-189.

Goto, D., Wallace, W.G., 2007. Interaction of $\mathrm{Cd}$ and $\mathrm{Zn}$ during uptake and loss in the polychaete Capitella capitata: whole body and subcellular perspectives. J. Exp. Mar. Biol. Ecol. $352,65-77$.

Goto, D., Wallace, W.G., In press. Relevance of intracellular partitioning of metals in prey to differential metal bioaccumulation among populations of mummichogs (Fundulus heteroclitus). Mar. Environ. Res. doi:10.1016/j.marenvres.2009.06.015

Hamza-Chaffai, A., Cosson, R.P., Amiard-Triquet, C., El-Abed, A., 1995. Physico-chemical forms of storage of metals $(\mathrm{Cd}, \mathrm{Cu}$ and $\mathrm{Zn})$ and metallothionein-like proteins in gills and liver of marine fish from the Tunisian coast: ecotoxicological consequences. Comp. Biochem. Physiol. C. $111,329-341$.

Khan, A.T., Weis, J.S., 1993. Bioaccumulation of heavy metals in two populations of mummichog (Fundulus heteroclitus). Bull. Environ. Contam. Toxicol. 51, 1-5. 
Klerks, P.L., Levinton, J.S., 1989. Rapid evolution of metal resistance in a benthic oligochaete inhabiting a metal polluted site. Biol. Bull. 176, 135-141.

Klerks, P.L., Weis, J.S., 1987. Genetic adaptation to heavy metals in aquatic organisms: a review. Environ. Pollut. 45, 173-205.

Kneib, R.T., 1986. The role of Fundulus heteroclitus in salt marsh trophic dynamics. Am. Zool. 26, 259-269.

Kneib, R.T., Stiven, A.E., Haines, E.B., 1980. Stable carbon isotope ratios in Fundulus heteroclitus (L.) muscle tissue and gut contents from a North Carolina Spartina marsh. J. Exp. Mar. Biol. Ecol. 46, 89-98.

Kraemer, L.D., Campbell, P.G.C., Hare, L., 2006. Seasonal variations in hepatic Cd and Cu concentrations and in the sub-cellular distribution of these metals in juvenile yellow perch (Perca flavescens). Environ. Pollut. 142,313-325.

Langston, W.J., Bebianno, M.J., Burt, G.R., 1998. Metal handling strategies in molluscs. in: W.J., L., Bebianno, M.J. (Eds.), Metal metabolism in aquatic environments. Kluwer Academic Publishers, London, pp. 219-283.

Luoma, S.N., 1996. The developing framework of marine ecotoxicology: pollutants as a variable in marine ecosystems? J. Exp. Mar. Biol. Ecol. 200, 29-55.

Masala, O., O’Brien, P., Rainbow, P.S., 2004. Analysis of metal-containing granules in the barnacle Tetraclita squamosa. J. Inorg. Biochem. 98, 1095-1102. 
Mason, A.Z., Jenkins, K.D., 1995. Metal detoxification in aquatic organisms. in: Tessier, A., Turner, D.R. (Eds.), Metal speciation and bioavailability in aquatic systems. John Wiley \& Sons, Chichester, pp. 479-609.

Mason, A.Z., Nott, J.A., 1981. The role of intracellular biomineralized granules in the regulation and detoxification of metals in gastropods with special reference to the marine prosobranch Littorina littorea. Aquat. Toxicol. 1, 239-256.

McMahon, K.W., Johnson, B.J., Ambrose, W.G., 2005. Diet and movement of the killifish, Fundulus heteroclitus, in a Maine salt marsh assessed using gut contents and stable isotope analyses. Estuaries 28, 966-973.

Morgan, A.J., Kille, P., Stuerzenbaum, S.R., 2007. Microevolution and ecotoxicology of metals in invertebrates. Environ. Sci. Technol. 41, 1085-1096.

Ng, T.Y.-T., Wang, W.-X., 2005. Modeling of cadmium bioaccumulation in two populations of the green mussel Perna viridis. Environ. Toxicol. Chem. 24, 2299-2305.

Nixon, S.W., Oviatt, C.A., 1973. Ecology of a New England salt marsh. Ecol. Monogr. 43, 463498.

Raimundo, J., Vale, C., Duarte, R., Moura, I., 2008. Sub-cellular partitioning of Zn, Cu, Cd and $\mathrm{Pb}$ in the digestive gland of native Octopus vulgaris exposed to different metal concentrations (Portugal). Sci. Total Environ. 390, 410-416.

Rountree, R.A., Able, K.W., 1992. Fauna of polyhaline subtidal marsh creeks in southern New Jersey: composition, abundance and biomass. Estuaries 15, 171-185. 
Sauer, G.R., Watabe, N., 1984. Zinc uptake and its effect on calcification in the scales of the mummichog, Fundulus heteroclitus. Aquat. Toxicol. 5, 51-66.

Sauer, G.R., Watabe, N., 1989. Temporal and metal-specific patterns in the accumulation of heavy metals by the scales of Fundulus heteroclitus. Aquat. Toxicol. 14, 233-248.

Seebaugh, D.R., Goto, D., Wallace, W.G., 2005. Bioenhancement of cadmium transfer along a multi-level food chain. Mar. Environ. Res. 59, 473-491.

Voets, J., Redeker, E.S., Blust, R., Bervoets, L., 2009. Differences in metal sequestration between zebra mussels from clean and polluted field locations. Aquat. Toxicol. 93, 53-60.

Wallace, W.G., Lee, B.-G., Luoma, S.N., 2003. Subcellular compartmentalization of Cd and Zn in two bivalves. I. Significance of metal-sensitive fractions (MSF) and biologically detoxified metal (BDM). Mar. Ecol. Prog. Ser. 249, 183-197.

Wallace, W.G., Lopez, G.R., Levinton, J.S., 1998. Cadmium resistance in an oligochaete and its effect on cadmium trophic transfer to an omnivorous shrimp. Mar. Ecol. Prog. Ser. 172, 225237.

Wang, W.-X., Rainbow, P.S., 2005. Influence of metal exposure history on trace metal uptake and accumulation by marine invertebrates. Ecotoxicol. Environ. Safety 61, 145-159.

Wang, W.-X., Rainbow, P.S., 2006. Subcellular partitioning and the prediction of cadmium toxicity to aquatic organisms. Environ. Chem. 3, 395-399.

Weis, J.S., 2002. Tolerance to environmental contaminants in the mummichog, Fundulus heteroclitus. Hum. Ecol. Risk Assess. 8, 933-953. 
Weis, J.S., Samson, J., Zhou, T., Skurnick, J., Weis, P., 2001. Prey capture ability of mummichogs (Fundulus heteroclitus) as a behavioral biomarker for contaminants in estuarine systems. Can. J. Fish. Aquat. Sci. 58, 1442-1452.

Weis, P., Weis, J.S., 1999. Accumulation of metals in consumers associated with chromated copper arsenate-treated wood panels. Mar. Environ. Res. 48, 73-81.

\section{Figure captions}

Fig. 1. Map of study sites in the Arthur Kill (Mill Creek, Richmond Creek, Main Creek, and Neck Creek), New York Harbor (Great Kills Harbor) and Raritan Bay (Lemon Creek), New York.

Fig. 2. Percentages (\%) of (a) $\mathrm{Cd}$, (b) $\mathrm{Pb}$, (c) $\mathrm{Cu}$, and (d) $\mathrm{Zn}$ partitioned to heat-denatured proteins (HDP), organelles (ORG), heat-stable proteins (HSP), metal-rich granules (MRG), and "cellular debris" (CD) in mummichogs from the study sites. MRG (cross-hatched gray bars) + HSP (cross-hatched white bars) = biologically detoxified metals (BDM). HDP (gray bars) + ORG $($ white bars $)=$ metal-sensitive fractions $(\mathrm{MSF})$.

Fig. 3. Relationships between concentrations ( $\mu \mathrm{g} \cdot \mathrm{g}^{-1}$ dry weight) of (a) $\mathrm{Cd},(\mathrm{b}) \mathrm{Pb},(\mathrm{c}) \mathrm{Cu}$, or (d) Zn partitioned to intracellular fractions [metal-rich granules ( $\nabla, M R G)$, heat-stable proteins $(\diamond$, HSP), organelles ( $\square$, ORG), and heat-denaturable proteins $(\bullet$, HDP)] and the whole body burdens in mummichogs from the study sites. Solid lines indicate regression for MRG; dashdotted lines indicate regression for HSP; dashed lines indicate regression for ORG; and dotted lines indicate regression for HDP. 


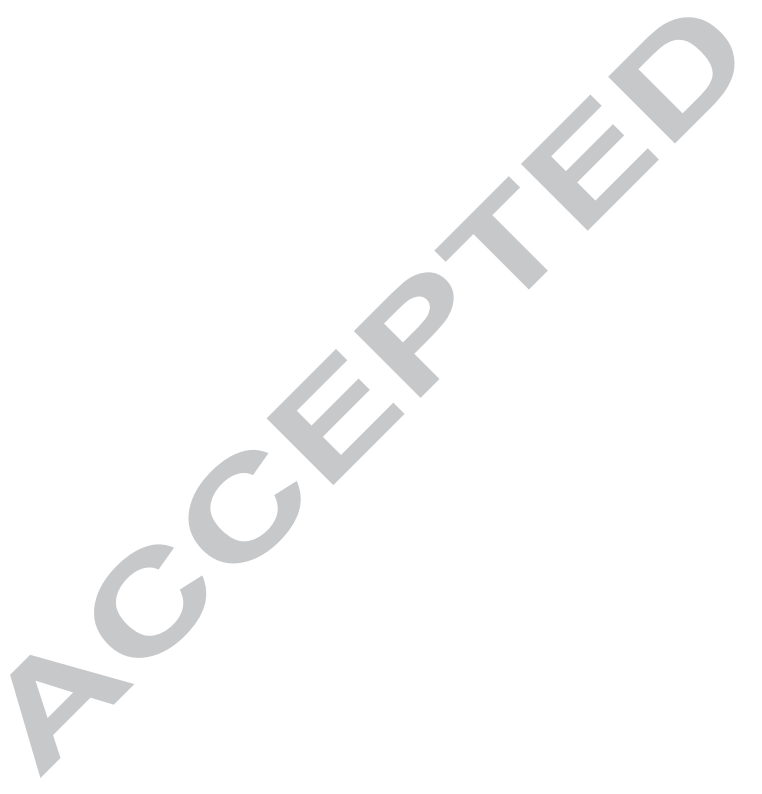


Table 1

Mean concentrations $\left(\mu \mathrm{g} \cdot \mathrm{g}^{-1}\right.$ dry weight $\pm \mathrm{SE}$ ) of metals in sediments and grass shrimp (Palaemonetes pugio) collected from the study sites

\begin{tabular}{|c|c|c|c|c|c|c|c|}
\hline \multirow[b]{2}{*}{ Trace metals ${ }^{\mathrm{a}, \mathrm{b}}$} & \multirow[b]{2}{*}{$\mathrm{ERM}^{\mathrm{c}}$} & \multirow[b]{2}{*}{ Lemon Creek } & \multirow[b]{2}{*}{ Great Kills Harbor } & \multicolumn{2}{|c|}{ Study sites } & \multirow[b]{2}{*}{ Neck Creek } & \multirow[b]{2}{*}{ Mill Creek } \\
\hline & & & & Richmond Creek & Main Creek & & \\
\hline \multicolumn{8}{|l|}{ Sediments } \\
\hline $\mathrm{Cd}$ & 9.6 & $1.2 \pm 0.08$ & $1.1 \pm 0.10$ & $1.6 \pm 0.16$ & $2.9 \pm 0.01$ & $1.1 \pm 0.02$ & $2.9 \pm 0.09$ \\
\hline $\mathrm{Pb}$ & 218 & $84 \pm 6.6$ & $99 \pm 6.6$ & $92 \pm 8.4$ & $170 \pm 15$ & $220 \pm 4.2$ & $\mathbf{6 6 0} \pm 110$ \\
\hline $\mathrm{Cu}$ & 270 & $130 \pm 16$ & $92 \pm 8.6$ & $100 \pm 10$ & $220 \pm 7.6$ & $230 \pm 3.3$ & $1400 \pm 310$ \\
\hline $\mathrm{Zn}$ & 410 & $220 \pm 4.0$ & $240 \pm 31$ & $290 \pm 34$ & $410 \pm 17$ & $340 \pm 1.5$ & $1200 \pm 15$ \\
\hline $\mathrm{Hg}$ & 0.71 & $0.43 \pm 0.03$ & $0.46 \pm 0.03$ & $1.3 \pm 0.33$ & $3.0 \pm 0.09$ & $3.9 \pm 0.14$ & $1.6 \pm 0.05$ \\
\hline \multicolumn{8}{|l|}{ Grass shrimp } \\
\hline $\mathrm{Cd}$ & & $0.071 \pm 0.02$ & $0.048 \pm 0.01$ & $0.088 \pm 0.01$ & $0.085 \pm 0.02$ & $0.063 \pm 0.01$ & $0.083 \pm 0.01$ \\
\hline $\mathrm{Pb}$ & & $0.49 \pm 0.14$ & $0.87 \pm 0.17$ & $0.74 \pm 0.09$ & $0.74 \pm 0.19$ & $0.72 \pm 0.06$ & $1.2 \pm 0.24$ \\
\hline $\mathrm{Cu}$ & & $180 \pm 47$ & $140 \pm 34$ & $130 \pm 4.6$ & $130 \pm 8.2$ & $180 \pm 10$ & $200 \pm 23$ \\
\hline $\mathrm{Zn}$ & & $79 \pm 0.70$ & $82 \pm 1.7$ & $89 \pm 6.1$ & $87 \pm 1.4$ & $100 \pm 7.7$ & $100 \pm 1.5$ \\
\hline
\end{tabular}

${ }^{\mathrm{a}}$ Sources of the data: Goto and Wallace (In press).

${ }^{\mathrm{a}}$ Data were based on samples collected in 2004, except for the data of $\mathrm{Zn}$ in grass shrimp, which were based on the 2001 samples.

${ }^{\mathrm{c}} \mathrm{ERM}=$ Effects Range Median, which indicates the threshold levels of sediment-associated metals for potential adverse effects in organisms (Long and Morgan, 1990). Metal concentrations above the ERM levels are indicated in bold. 
Table 2

Mean whole body burdens $\left(\mu \mathrm{g} \cdot \mathrm{g}^{-1}\right.$ dry weight $\left.\pm \mathrm{SE}\right)$ of $\mathrm{Cd}, \mathrm{Pb}, \mathrm{Cu}$, and $\mathrm{Zn}$ in mummichogs $(n=$ 10) collected from the study sites

\begin{tabular}{ccccc}
\hline Study sites & $\mathrm{Cd}$ & $\mathrm{Pb}$ & $\mathrm{Cu}$ & $\mathrm{Zn}$ \\
\hline Lemon Creek & $0.031 \pm 0.005$ & $0.74 \pm 0.067_{\mathrm{A}}$ & $14 \pm 2.5$ & $140 \pm 7.1$ \\
Great Kills Harbor & $0.024 \pm 0.003$ & $0.72 \pm 0.062_{\mathrm{A}}$ & $9.0 \pm 1.8$ & $160 \pm 14$ \\
Richmond Creek & $0.041 \pm 0.006$ & $0.67 \pm 0.086_{\mathrm{A}}$ & $8.0 \pm 0.91$ & $180 \pm 8.3$ \\
Main Creek & $0.055 \pm 0.018$ & $0.78 \pm 0.092_{\mathrm{A}}$ & $11 \pm 1.6$ & $180 \pm 28$ \\
Neck Creek & $0.029 \pm 0.009$ & $0.67 \pm 0.046_{\mathrm{A}}$ & $12 \pm 1.2$ & $160 \pm 8.7$ \\
Mill Creek & $0.038 \pm 0.006$ & $1.3 \pm 0.086_{\mathrm{B}}$ & $12 \pm 2.2$ & $180 \pm 12$ \\
\hline
\end{tabular}

Different letters indicate statistically significant difference among the sites (one-way ANOVA followed by Tukey's HSD test, $p<0.05$ ). 


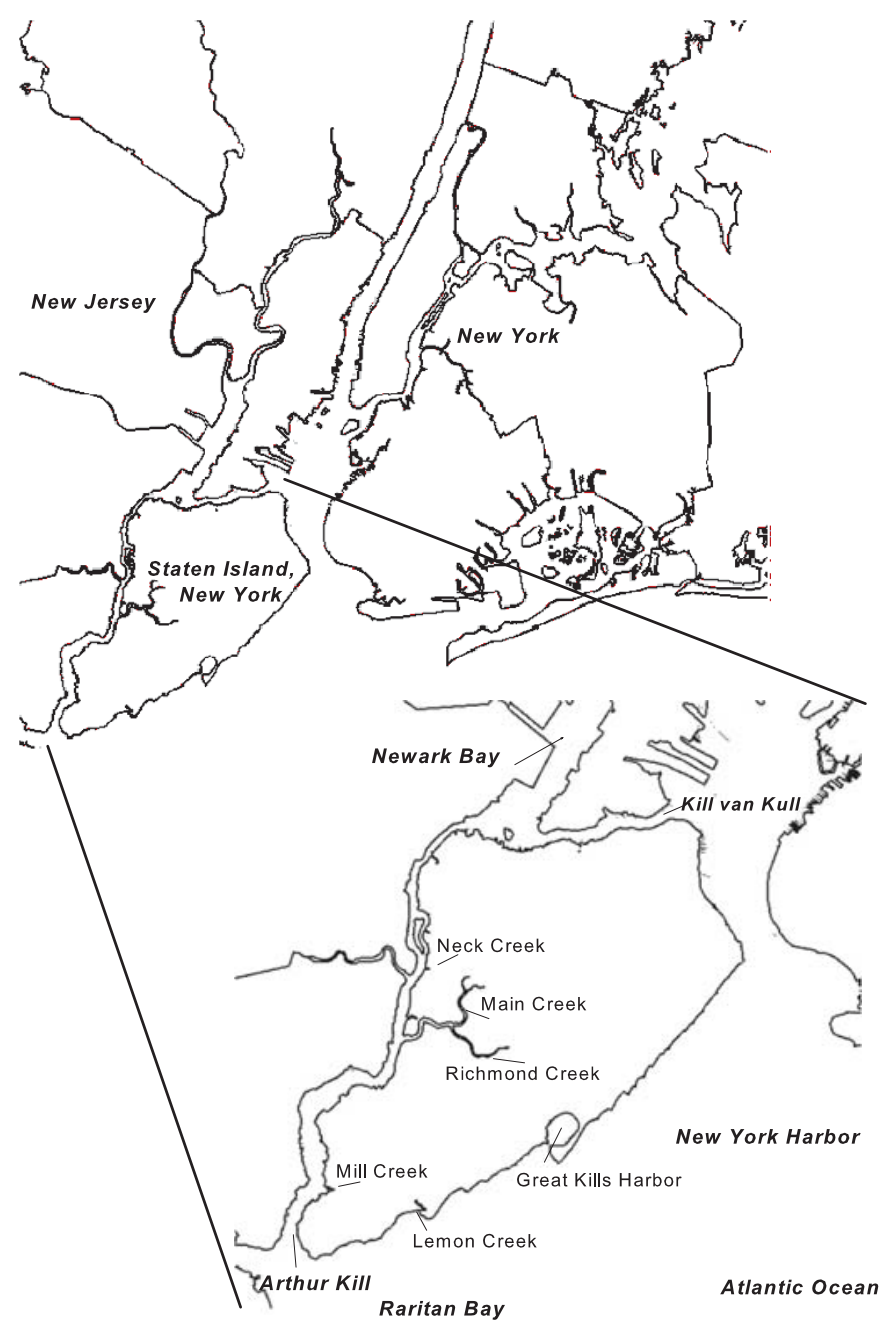



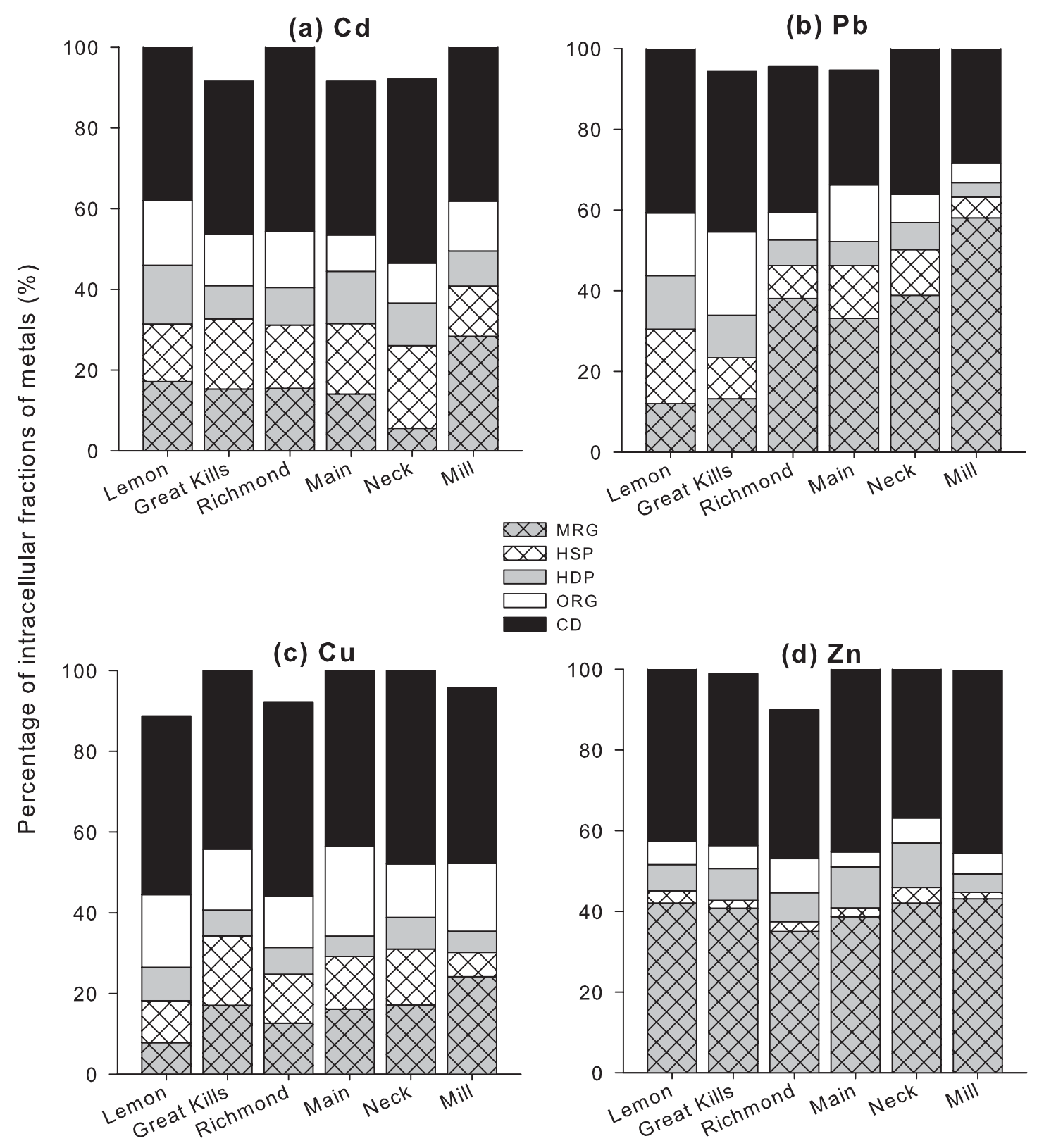


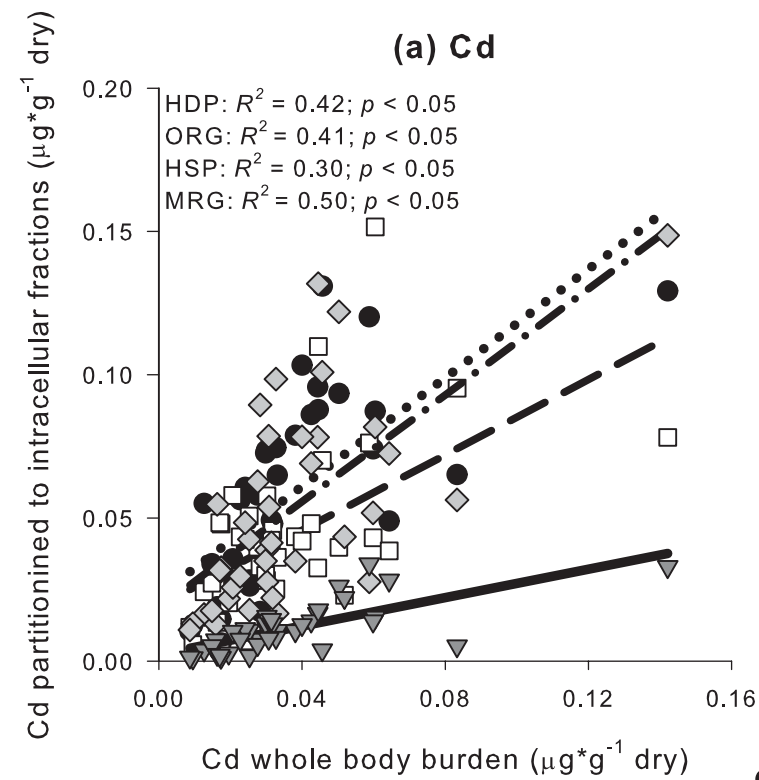

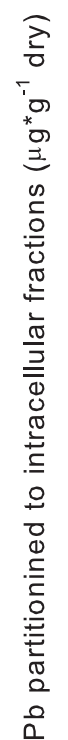

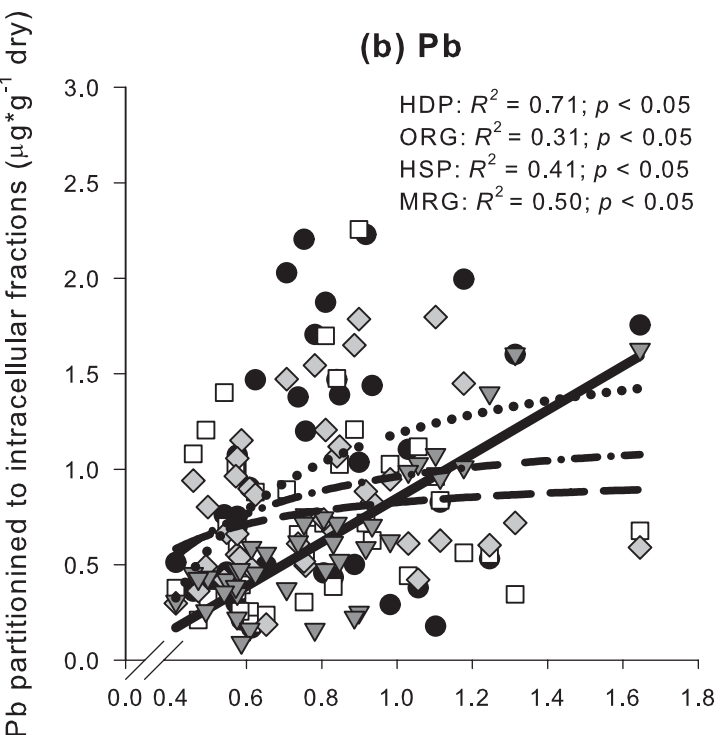

- HDP Pb whole body burden $\left(\mu \mathrm{g}^{*} \mathrm{~g}^{-1} \mathrm{dry}\right)$

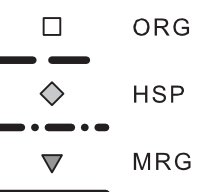

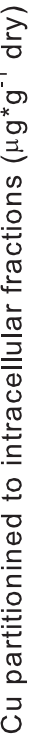

(c) $\mathrm{Cu}$

507 HDP: $R^{2}=0.32 ; p<0.05$

ORG: $R^{2}=0.35 ; p<0.05$

HSP: $R^{2}=0.44 ; p<0.05$

$40-\mathrm{MRG}: R^{2}=0.57 ; p<0.05$

$30-\square$

$30-\square \diamond \square$

$20-$
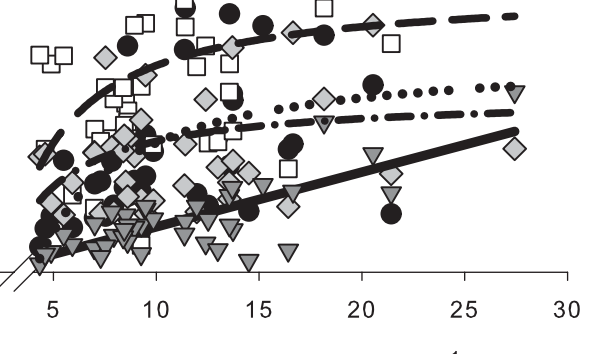

Cu whole body burden $\left(\mu \mathrm{g}^{*} \mathrm{~g}^{-1}\right.$ dry) (d) $\mathrm{Zn}$

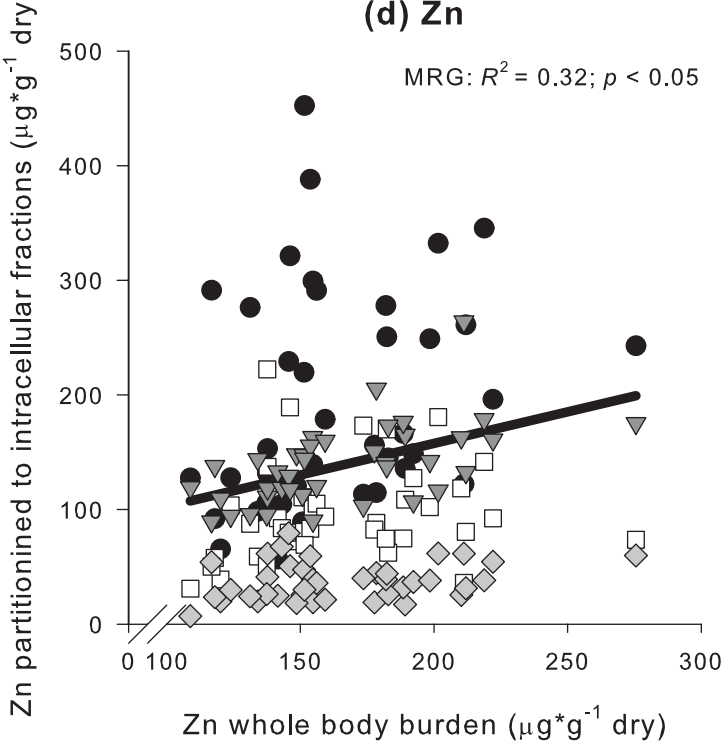

